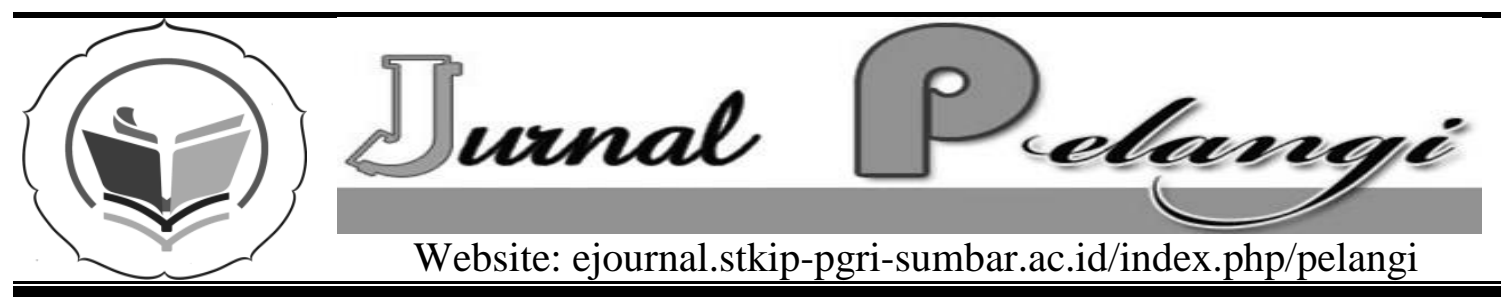

\title{
PENINGKATAN KETERAMPILAN MENULIS PARAFRASE MENGGUNAKAN METODE MIND MAPPING
}

\author{
Salmiati \\ SD Negeri 16 Kampung Parit, Agam \\ salmiati@yahoo.co.id
}

\section{INFO ARTIKEL}

\section{Diterima:}

1 Desember 2015

Direview:

12 Desember 2015

Disetujui:

22 Desember 2015

Kata Kunci:

Keterampilan Menulis, Mind Mapping,

Prafrase

\begin{abstract}
Abstrak
Penelitian dilatarbelakangi kenyataan di Sekolah Dasar bahwa pembelajaran sering didominasi oleh guru sebagai sumber informasi. Berdasarkan pengamatan, ditemukan hasil belajar siswa rendah. Metode Mind Mapping digunakan untuk meningkatkan keterampilan menulis parafrase. Tujuan penelitian ini untuk peningkatan keterampilan menulis parafrase dengan menggunakan metode mind mapping pada siswa kelas VI SD Negeri 16 Kampung Parit Kecamatan Ampek Nagari Kab. Agam. Jenis penelitian ini adalah Penelitian Tindakan Kelas (classroom action research). Penelitian ini menggunakan empat tahap tindakan, yaitu tahap perencanaan, tindakan, observasi dan refleksi. Sumber data adalah proses pelaksanaan pembelajaran dengan metode mind mapping dikelas VI SD Negeri 16 Kampung Parit Kecamatan Ampek Nagari. Subjek penelitian adalah siswa kelas VI yang berjumlah 20 orang. Teknik pengumpulan data yang digunakan adalah observasi, pencatatan lapangan, dan tes. Hasil penelitian menunjukan bahwa rata-rata nilai siklus I adalah 50, pada siklus II hasil belajar siswa yaitu 84,75. Setelah dilakukan penelitian terungkap bahwa penggunaan metode mind mapping dapat meningkatkan keterampilan menulis parafrase siswa.
\end{abstract}

\section{Abstract}

The background of the research is the fact that the learning in Elementary School is often dominated by the teacher as a source of information. Based on the researcher observation, it is found that there is a low learning outcome. The researcher used mind mapping method to improve the paraphrasing writing skill. The purpose of the research is to improve the paraphrasing writing skill by using mind mapping method to class VI Students Elementary School 16 Kampung Parit Kecamatan Ampek Nagari, Agam Regency. The type of 
the research is Classroom Action Research (CAR). It used 4 stages, i.e. planning, implementing, observing and reflecting. Source of data was the learning implementation process by using mind mapping method in Class VI Students Elementary School 16 Kampung Parit Kecamatan Ampek Nagari, Agam Regency. The subject of the research was the class VI students, i.e. 20 students. The data collecting techniques were observation, field note, and test. The result shows that the average score in the first cycle is 50, and in the second cycle is 84,75 . After conducting the research, it is found that the using mind mapping method can increase the paraphrasing writing skill of students.

\section{PENDAHULUAN}

Tujuan umum pembelajaran bahasa Indonesia adalah siswa terampil dalam bahasa yang mencakup aspek mendengarkan, berbicara, membaca, menulis, dan apresiasi sastra. Dalam Badan Standar Nasional Pendidikan (2006:317) juga dijelaskan bahwa pembelajaran bahasa Indonesia bertujuan agar peserta didik memiliki kemampuan untuk. Ruang lingkup pembelajaran bahasa Indonesia mencakup komponen kemampuan berbahasa dan kemampuan bersastra yang meliputi 4 aspek, yaitu: mendengar, berbicara, membaca, dan menulis. Keempat keterampilan berbahasa tersebut merupakan satu kesatuan yang tidak dapat dipisahkan satu sama lain, tetapi hanya dapat dibedakan. Keterampilan yang satu bergantung pada keterampilan yang lainnya. Seseorang dapat berbicara karena ia mampu menyimak, atau terampil membaca dan menulis. Demikian pula seorang terampil menulis, jika ia terampil menyimak, berbicara dan membaca. Pembelajaran menulis merupakan salah satu komponen yang turut menentukan dalam mencapai tujuan pembelajaran bahasa Indonesia di SD.

Menurut Novi (2008:115) menulis merupakan komponen penggunaan bahasa yang harus diajarkan di SD dengan tujuan siswa mampu mengungkapkan gagasan, pendapat, pengalaman, dan perasaan secara tertulis dengan benar. Senada dengan itu Rusyana (dalam Isah, 2007:97) mengatakan bahwa menulis merupakan kegiatan mengutarakan sesuatu secara tertulis dengan menggunakan bahasa terpilih dan tersusun sehingga orang lain atau pembaca dapat memahami makna yang ingin disampaikan oleh penulis. Jadi, bahan pokok dalam pembelajaran sastra adalah bahasa, baik bahasa lisan maupun bahasa tulisan.

Puisi merupakan salah satu karya sastra yang menggunakan bahasa sebagai medianya untuk menyampaikan pikiran dan perasaan. Pembelajaran menulis puisi di SD bertujuan untuk memberikan pemahaman terhadap puisi lebih dini kepada siswa, baik pemahaman terhadap isi puisi maupun makna yang ada dalam puisi tersebut.

Parafrase merupakan salah satu cara untuk memahami puisi, seperti yang 
diungkapkan oleh Hadi (2010:1) bahwa "Salah satu cara untuk memahami puisi adalah dengan memparafrasekan puisi tersebut dengan cara menambahkan kata-kata yang dapat memperjelas kalimat pendek yang menjadi ciri khas puisi". Guru dalam pembelajaran belum mampu mencari strategi alternatif yang lebih cocok dan belum adanya inovasi atau pembaharuan metode yang digunakan dalam pembelajaran menulis parafrase.

Selama ini, guru masih menggunakan metode ceramah atau sebatas memberikan informasi kepada siswa mengenai pengertian parafrase dan selanjutnya guru langsung meminta siswa untuk menulis parafrase dari puisi tersebut. Dalam pembelajaran menulis parafrase guru tidak meminta siswa untuk menuliskan terlebih dahulu tema dari puisi yang akan diparafrasekan. Padahal menuliskan tema dari puisi yang akan diparafrasekan sangat penting dalam langkah awal pembelajaran menulis parafrase. Selanjutnya, dalam pembelajaran menulis parafrase guru kurang bisa membangkitkan imajinasi siswa, padahal imajinasi siswa dapat dibangkitkan melalui gambar berwarna karena otak akan cepat berfikir dan mengingat dalam bentuk gambar dan warna. Hal tersebut senada dengan pendapat Tony (2007:12) bahwa otak akan berfikir dan mengingat dalam bentuk gambar dan warna.

Berdasarkan permasalahan yang ada dan pendapat di atas penulis mencoba menggunakan metode mind mapping dalam pembelajaran menulis parafrase. Dalam metode mind mapping tersebut, pertama-tama siswa menuliskan satu kata kunci dari tema yang dipilih di tengah kertas. Tema tersebut dijabarkan dalam bentuk ranting-ranting. Pada dasarnya, dengan metode ini siswa dituntut untuk menulis perencanaan sebelum menulis parafrase.

Kata kunci atau tema dalam metode ini dilengkapi dengan gambar berwarna yang dipetakan. Selain lebih menarik, kelebihan lain dari mind mapping adalah siswa dapat menambah kata kunci di manapun jika di tengah kegiatan menulis ia mendapatkan ide baru. Mind mapping tersebut dapat terus berkembang sesuai dengan keinginan penulisnya. Dengan demikian, dalam metode mind mapping ini siswa dibebaskan untuk menulis sesuai dengan keinginan serta kreativitasnya. Di samping itu, simbol serta gambar berwarna yang digunakan dalam mind mapping ini berpotensi mengoptimalkan fungsi kerja otak kanan yang memacu kreativitas serta imajinasi sehingga diharapkan siswa tidak kehabisan ide dalam menulis parafrase (Tony, 2008:13).

Menurut Tarigan (dalam Novi, 2008:115) menulis adalah menurunkan atau melukiskan lambang-lambang grafik yang menggambarkan suatu bahasa yang dipahami oleh seseorang, sehingga orang lain dapat membaca lambang-lambang grafik tersebut kalau mereka memahami bahasa gambar itu. Dengan menulis dapat terjadi komunikasi antara penulis dan pembaca. Selanjutnya Rusyana (dalam Isah, 2007:97) mengungkapkan bahwa menulis adalah mengutarakan sesuatu secara tertulis dengan menggunakan bahasa terpilih dan tersusun. Hal ini 
mencerminkan bahwa menulis merupakan suatu proses.

Murray (dalam Saleh, 2006:127) mengatakan bahwa menulis adalah proses berfikir yang berkesinambungan, mulai dari mencoba, dan sampai dengan mengulas kembali. Menulis sebagai proses berfikir berarti bahwa sebelum atau saat setelah menuangkan gagasan dan perasan secara tertulis diperlukan keterlibatan proses berfikir.

Proses berfikir menurut Pappas (dalam Saleh, 2006:127) merupakan proses yang bersifat aktif, konstruktif dan menuangkan gagasan berdasarkan skemata, pengetahuan dan pengalaman yang dimiliki secara tertulis. Dalam proses tersebut diperlukan kesungguhan mengolah, menata, mempertimbangkan secara kritis dan menata ulang gagasan yang dicurahkan. Hal tersebut diperlukan agar tulisan yang dihasilkan dapat dipahami pembaca dengan baik. Menulis sebagai keterampilan adalah kemampuan seseorang dalam mengemukakan gagasan pikirannya kepada orang atau pihak lain dengan menggunakan media tulisan (Rina, 2010:2). Berdasarkan pendapat di atas dapat disimpulkan bahwa menulis merupakan sebuah proses kreatif dalam menuangkan ide atau gagasan dalam bentuk bahasa tulis dengan tujuan tertentu.

Tujuan menulis menurut Rachmad (dalam wywid, 2009:3) adalah 1) menginformasikan segala sesuatu, 2) membujuk, 3) mendidik, dan 4) menghibur. Senada dengan itu Fauzan (2009:1) mengemukakan bahwa tujuan menulis adalah untuk 1) memberi informasi , 2) menjelaskan tulisan yang menganalisis/menguraikan mengapa suatu peristiwa, 3) mengarahkan tulisan, 4) membujuk/meyakinkan orang, dan 5) meringkaskan/membuat rangkuman dari suatu karya. Hugo (dalam Muchlisoh, 1994:255-256) memaparkan tujuan yang ingin dicapai penulis dalam membuat suatu tulisan adalah untuk 1) memenuhi tugas, 2) menghibur pembaca, 3) membujuk pembaca agar mengikuti kemamuan penulis, 4) memberikan informasi, 5) memperkenalkan diri pada pembaca, 6) mengembangkan kreativitas, dan 7) memberikan penjelasan kepada pembaca tentang bagaimana cara memecahkan suatu masalah. Berdasarkan pendapat di atas dapat disimpulkan bahwa tujuan menulis adalah memberikan informasi kepada pembaca, baik itu sebuah peristiwa, masalah, berita, dan pernyataan yang tujuannya untuk menghibur pembaca.

Tarigan (1997:8.20) mengemukakan "parafrase adalah mengungkapkan kembali suatu informasi dengan bahasa sendiri". Selanjutnya dalam kamus umum bahasa Indonesia (1982: 711) parafrase adalah 1) Pengungkapan kembali suatu tuturan dari sebuah tingkatan atau macam bahasa menjadi macam yang lain tanpa mengubah pengertiannya, 2) Penguraian kembali sebuah teks dalam bentuk yang lain, dengan maksud untuk dapat menjelaskan makna yang tersembunyi. Parafrase mengandung arti pengungkapan kembali suatu tuturan atau karangan menjadi bentuk lain namun tidak mengubah pengertian awal (Evanz, 2010:3). Parafrase dapat dilakukan dengan cara pengubahan susunan kata, penggantian kata dengan kata lain yang sinonim (sama maknanya) atau penyingkatan 
kalimat. Parafrase juga berarti mengungkapkan informasi dari suatu bentuk ke bentuk lain yang berbeda, seperti dari prosa ke puisi atau sebaliknya dari bentuk puisi ke dalam bentuk prosa.

Berdasarkan pendapat di atas dapat disimpulkan bahwa parafrase adalah pengungkapan suatu informasi ke dalam bentuk lain namun tidak megubah makna atau pengertian awal. Sedangkan parafrase puisi adalah mengubah puisi menjadi bentuk sastra lain (prosa) yang berarti bahwa puisi yang tunduk pada aturan-aturan puisi diubah menjadi prosa yang tunduk pada aturan-aturan prosa tanpa mengubah isi puisi tersebut. Dengan kata lain, parafrase puisi adalah memprosakan puisi. Parafrase merupakan metode memahami puisi, bukan metode membuat karya sastra. Dengan demikian, memparafrasekan puisi tetap dalam kerangka upaya memahami puisi.

Menurut Rachmad (dalam wywid, 2009:1) unsur Parafrase yaitu 1) Parafrase Kalimat artinya memisahkan/memenggal sebuah kalimat menjadi beberapa kata menurut jabatannya, 2) Parafrase Suku Kata artinya memisahkan/memenggal sebuah kata menurut suku katanya, 3) Parafrase Puisi artinya mengubah bentuk puisi ke bentuk prosa/narasi.

Metode parafrase puisi, yaitu a) Parafrase terikat, yaitu mengubah puisi menjadi prosa dengan cara menambahkan sejumlah kata pada puisi sehingga kalimat-kalimat puisi mudah dipahami. Seluruh kata dalam puisi masih tetap digunakan dalam parafrase tersebut, b) Parafrase bebas, yaitu mengubah puisi menjadi prosa dengan kata-kata sendiri. Kata-kata yang terdapat dalam puisi dapat digunakan, dapat pula tidak digunakan. Setelah kita membaca puisi tersebut kita menafsirkan secara keseluruhan, kemudian menceritakan kembali dengan kata-kata sendiri.

Metode parafrase yang digunakan dalam penelitian ini adalah metode parafrase bebas yaitu menceritakan puisi tersebut dengan kata-kata sendiri tetapi tidak mengubah makna puisi tersebut.

Kegiatan parafrase dalam pembelajaran menurut Tarigan (1997: 11.4) dapat dilakukan melalui langkahlangkah sebagai berikut: 1) membaca dan memahami secara keseluruhan suatu karya sastra, 2) memahami jenis perubahan yang akan dilakukan baik bentuknya berupa puisi, prosa, atau drama amupun redaksinya atau penggunaan bahasanya, dan 3) mengungkapkan kembali dengan redaksi bahasa dan bentuk yang berbeda. Evanz (2010:3) mengemukakan langkahlangkah menulis parafrase adalah sebagai berikut: a) bacalah naskah yang akan diparafrasakan sampai selesai untuk memperoleh gambaran umum isi bacaan/tulisan, b) bacalah naskah sekali lagi dengan memberi tanda pada bagianbagian penting dan kata-kata kunci yang terdapat pada bacaan, c) catatlah kalimat inti dan kata-kata kunci secara berurut, d) kembangkan kalimat inti dan katakata kunci menjadi gagasan pokok yang sesuai dengan topik bacaan, dan e) uraikan kembali gagasan pokok menjadi paragraf yang singkat dengan bahasa sendiri. Hal-hal yang harus diperhatikan dalam memprosakan sebuah puisi 
menurut Mursal (1992:43) adalah sebagai berikut: 1) kalimat-kalimat merupakan kalimat berita, tidak ada lagi kalimat langsung, dan 2) kata ganti yang ada di dalam parafrase hanyalah kata ganti orang ketiga (tunggal atau jamak). Kata ganti orang pertama dan orang kedua diubah menjadi kata ganti orang ketiga. Dari pendapat di atas dapat disimpulkan bahwa langkah-langkah dalam menulis parafrase adalah dengan membaca karya sastra tersebut, menentukan jenis perubahan yang akan dilakukan dan kemudian mengungkapkannya dalam bentuk yang berbeda dengan bahasa sendiri.

Peta pikiran atau disebut dengan mind mapping merupakan salah satu metode belajar yang dikembangkan oleh Tony Buzan tahun 1970-an yang didasarkan pada cara kerja otak. Mind mapping disebut sebagai metode karena berupa urutan langkah-langkah yang sistematis. Otak mengingat informasi dalam bentuk gambar, simbol, bentukbentuk, suara musik, dan perasaan. Otak menyimpan informasi dengan pola dan asosiasi seperti pohon dengan cabang dan rantingnya. Otak tidak menyimpan informasi menurut kata demi kata atau kolom demi kolom dalam kalimat baris yang rapi seperti yang kita keluarkan dalam berbahasa. Untuk mengingat kembali dengan cepat apa yang telah kita pelajari sebaiknya meniru cara kerja otak dalam bentuk peta pikiran.

Peta pikiran adalah alternatif pemikiran keseluruhan otak terhadap pemikiran linear. Mind mapping menggapai ke segala arah dan menangkap berbagai pikiran dari segala sudut (Michael dalam Tony, 2007:2).
Senada dengan pendapat tersebut, Tony (2007: 103) mengungkapkan bahwa mind mapping adalah alat berpikir kreatif yang mencerminkan cara kerja alami otak. Mind mapping memungkinkan otak menggunakan semua gambar dan asosiasinya dalam pola radial dan jaringan sebagaiman otak dirancang seperti yang secara internal selalu digunakan otak, dan terhadap mana anda perlu membiasakan diri kembali.

Mind mapping merupakan cara termudah untuk menempatkan informasi ke dalam otak dan mengambil informasi ke luar dari otak. Mind mapping adalah cara mencatat yang kreatif, efektif, dan secara harfiah akan memetakan pikiranpikiran kita (Tony, 2007: 4). Mind mapping bisa dibandingkan dengan peta kota. Bagian tengah mind mapping sama halnya dengan pusat kota dan mewakili gagasan terpentng; jalan-jalan protokol yang memancar keluar dari pusat kota merupakan pikiran-pikiran utama dalam proses berpikir, jalan-jalan atau cabangcabang sekunder merupakan pikiran sekunder (Tony, 2007: 6).

Mind mapping yang ditemukan oleh Tony Buzan ini didasarkan pada cara kerja otak penyimpan informasi. Hasil penelitian menunjukkan bahwa otak manusia tidak menyimpan informasi dalam kotak-kotak sel saraf yang terjejer rapi melainkan dikumpulkan pada sel-sel saraf yang bercabang-cabang. Apabila dilihat sekilas sel-sel saraf tersebut akan tampak seperti cabang-cabang pohon. Dengan demikian jika informasi disimpan seperti cara kerja otak, maka akan informasi tersimpan makin baik 
dan hasil akhirnya membuat proses belajar semakin mudah.

Mind mapping merupakan sebuah cara mencatat dengan memanfaatkan bagaimana otak bekerja. Mind mapping merupakan sistem akses dan pengambilan kembali data yang ada dalam otak, membantu dalam belajar, mengatur dan menyimpan sebanyak mungkin informasi yang diinginkan, serta menggolongkan informasi tersebut secara wajar sehingga memungkinkan kita mengakses seketika dari segala hal yang diinginkan.

$\begin{array}{lr}\text { Menurut Nawaafila } & (2010: 2) \\ \text { "Manfaat mind mapping } & \text { adalah } \\ \text { mempercepat pembelajaran, } & \text { melihat }\end{array}$
koneksi antar topik yang berbeda, membantu dalam pencurahan gagasan, memudahkan ide mengalir, melihat gambaran besar, menyederhanakan struktur, dan membangkitkan ide-ide orisinal dan memicu ingatan dengan mudah". Menurut Toni (2008:4) mind mapping dapat membantu kita untuk 1) menjadi lebih kreatif, 2) menghemat waktu, 3) menyelesaikan masalah, 4) menyusun dan menjelaskan pikiranpikiran, dan 5) belajar lebih cepat dan efisien. Sebuah mind mapping memiliki sejumlah keuntungan-keuntungan disbanding bentuk pencatatan biasa. Keuntungan tersebut oleh Tony (2004: 106).

Bahan yang diperlukan sebelum membuat sebuah mind mapping yaitu kertas kosong tak bergaris, pena dan pensil warna, otak serta imajinasi. Tony (2007: 15) mengemukakan tujuh langkah untuk membuat mind mapping adalah sebagai berikut: "1) mulailah dari bagian tengah kertas kosong yang sisi panjangnya diletakkan mendatar, 2) gunakan gambar atau foto untuk ide sentral, 3) gunakan warna, 4) hubungkan cabang-cabang utama ke gambar pusat dan hubungkan cabang-cabang tingkat dua dan tiga ke tingkat satu dan dua, dan seterusnya karena otak bekerja menurut asosiasi, 5) buatlah garis hubung yang melengkung, bukan garis lurus karena garis lurus akan membosankan otak, 6) gunakan satu kata kunci untuk setiap garis karena kata kunci tunggal memberi lebih banyak daya dan fleksibilitas kepada peta pikiran, dan 7) gunakan gambar karena seperti gambar sentral, setiap gambar bermakna seribu kata".

Metode mind mapping sangat tepat digunakan dalam pembelajaran menulis. Wycoff (2003: 84) mengemukakan bahwa mind mapping adalah cara yang sangat baik untuk menghasilkan dan menata gagasan sebelum menulis. Bagian yang paling sulit dalam menulis adalah mengetahui hal apa yang akan tulis, apa temanya dan bagaimana memulainya.

Pada mind mapping, sebuah tema dijabarkan dalam ranting-ranting tema yang lain sehingga menjadi pengembang gagasan dalam menulis. Kreativitas dan imajinasi dalam menulis parafrase sangat diperlukan untuk mengembangkan ide menjadi sebuah prosa (cerita) yang menarik. Imajinasi dan kreativitas merupakan ranah kerja otak kanan. 


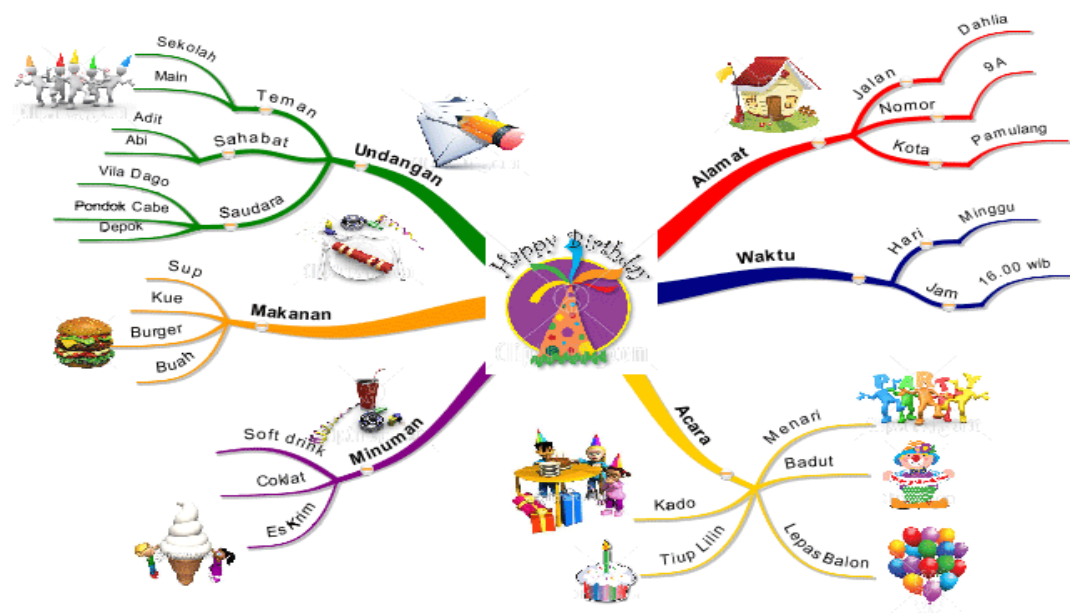

Gambar 1 Alur Metode Mind Mapping

Berdasarkan paparan sebelumnya, diketahui bahwa mind mapping dengan gambar, warna serta kata kuncinya dapat membangkitkan fungsi kerja otak kanan sehingga memunculkan ide-ide baru yang kreatif dan imajinatif. Lebih jauh, bila dibandingkan dengan metode konvensional yang selama ini diterapkan dalam pembelajaran menulis parafrase, metode mind mapping jauh lebih baik karena melibatkan kedua belahan otak untuk berpikir. Hal ini berbeda dengan metode konvensional yang biasanya masih bersifat teoretis praktis yang hanya berpotensi mengoptimalkan fungsi kerja otak kiri. Kreativitas dan imajinasi tidak terkembangkan dengan baik melalui metode konvensional tersebut. Oleh karena itu, metode mind mapping sangat baik untuk diterapkan dalam pembelajaran menulis parafraseyang tampak seperti Gambar 1.

\section{METODE PENELITIAN}

Penelitian yang dilakukan merupakan penelitian tindakan kelas dengan menggunakan pendekatan kualitatif. Menurut Kemmis (dalam Ritawati, 2007:9) "Proses penelitian tindakan merupakan proses daur ulang atau siklus yang dimulai dari aspek mengembangkan perencanaan, melakukan tindakan sesuai rencana, melakukan observasi tindakan dan melakukan refleksi yaitu perenungan terhadap perencanaan, kegiatan tindakan dan kesuksesan hasil yang diperoleh".

Partisipasi dan kolaborasi dapat dilakukan berupa hal-hal sebagai berkut: bekerja sama mulai dari tahap orientasi dilanjutkan dengan penyusunan berikut persiapan yang diperlukan, pelaksanaan perencanaan dalam siklus I, diskusidiskusi yang bersifat analitik setelah pelaksanaan tindakan, kemudian melakukan refleksi atas semua kegiatan yang telah berlangsung dalam siklus I, kemudian merencanakan tahap modifikasi, koreksi atau pembetulan ataupun penyempurnaan pembelajaran dalam siklus II, dan seterusnya (Rochiati, 2007: 100).

Penelitian tindakan kelas diawali dengan studi pendahuluan atau dikenal juga dengan istilah refleksi awal. Studi pendahuluan peneliti lakukan di SD Negeri 16 Kampung Parit Kecamatan Ampek Nagari. Di sekolah ini peneliti 
melakukan observasi terhadap proses pembelajaran menulis parafrase dan hasil parafrase yang terdapat dalam buku latihan menulisnya. Dari studi pendahuluan yang peneliti lakukan terlihat masalah-masalah praktis dalam hal menulis parafrase, yaitu: kalimat yang digunakan kurang runtut, ide yang tergambar kebanyakan kaku dan sempit. Di samping itu paragraf yang dibuat kurang padu atau kurang terlihat adanya hubungan antar paragraf. Setelah mendapatkan data berupa bukti hasil parafrase siswa yang masih jauh dari apa yang diharapkan ini, peneliti pun melakukan tanya jawab dengan 5 orang siswa SD Negeri 16 Kampung Parit Kecamatan Ampek Nagari.tentang pembelajaran menulis parafrase yang selama ini mereka terima. Untuk lebih memperjelas penyebab dari masalah kurangnya keterampilan menulis parafrase siswa, peneliti juga mengadakan wawancara dengan guru kelas VI dan guru-guru lainnya di SD Negeri 16 Kampung Parit Kecamatan Ampek Nagari, tentang pembelajaran menulis parafrase yang telah dilakukan selama ini. Peneliti membuat kesimpulan sementara dari hasil studi pendahuluan bahwa kurangnya keterampilan menulis parafrase siswa SD Negeri 16 Kampung Parit Kecamatan Ampek Nagari. disebabkan oleh faktor guru, siswa dan faktor lingkungan/sarana penunjang pembelajaran menulis parafrase yang kurang tepat.

Diskusi dilakukan dengan guru-guru di SD Negeri 16 Kampung Parit Kecamatan Ampek Nagari,tentang tindakan yang akan peneliti lakukan terhadap siswanya, ternyata guru-guru dan guru kelas VI SD Negeri 16 Kampung Parit Kecamatan Ampek Nagari setuju dengan rencana peneliti untuk melakukan penelitian di sekolah tersebut. Peneliti memberikan gambaran umum tentang tindakan yang akan peneliti lakukan di kelas VI dengan guru kelas VI untuk meningkatkan keterampilan menulis parafrase siswanya. Peneliti menjelaskan bahwa mind mapping di sini bukanlah sematamata sebagai suatu media dalam menulis parafrase, akan tetapi merupakan suatu cara untuk mengumpulkan data dari tema puisi yang akan diparafrasekan secara lebih terperinci, serta dapat mengatasi bolak-baliknya susunan kalimat dalam paragraf yang dibuat siswa. Kemudian jika siswa sudah mengumpulkan data dari tema puisi yang akan diparafrasekan, selanjutnya guru memandu siswa membuat kerangka karangan berdasarkan data dari tema puisi yang akan diparafrasekan yang telah dicantumkan dalam bentuk mind mapping tersebut.

Parafrase yang dibuat oleh siswa dengan menggunakan mind mapping diharapkan lebih baik kualitasnya. Baik dari segi ide, gaya bahasanya, dan mekanisme penulisannya. Setelah siswa membuat kerangka langkah selanjutnya adalah mengembangkan kerangka menjadi prosa dengan menggunakan pilihan-pilihan kata yang tepat. Kemudian tahap selanjutnya adalah tahap perevisian dan pengeditan serta pembublikasian dari parafrase yang telah dibuat. Pelaksanaan tindakan terdiri dari tiga tahap, yaitu tahap prapenulisan, tahap penulisan, dan tahap pascapenulisan. Pada tahap prapenulisan 


\section{Jurnal Pelangi}

dilakukan kegiatan penentuan tema puisi yang akan diparafrasekan, kemudian membuat mind mapping dari tema tersebut dengan cara 1) menuliskan tema di tengah kertas, 2) membuat gambar bewrna yang sesuia dengan tema puisi 3) menjabarkan tema tau membuat turunan dari tema utama dengan menggunakan garis lengkung dan diberi warna sehingga membentuk sebuah mind mapping.

Kegiatan observasi ini dilakukan untuk mengamati aktivitas siswa dan guru praktisi selama pembelajaran menulis parafrase dengan menggunakan metode mind mapping berlangsung. Pelaksanaaan bersamaan dengan tindakan yang dilakukan oleh observer pada waktu peneliti sebagai praktisi melaksanakan pembelajaran. Kegiatan observasi ini dilakukan oleh guru kelas dan teman sejawat. Guru kelas mengamati aktivitas guru praktisi sedangkan teman sejawat mengamati aktivitas yang dilakukan oleh siswa. Observer dalam kegiatan ini berusaha mengenal, merekam, atau mendokumentasikan semua indikator dari proses hasil perubahan yang terjadi. Keseluruhan hasil pengamatan ini dilakukan terus menerus dari siklus I sampai siklus berikutnya. Jika siklus I belum berhasil akan dilanjutkan pada siklus II. Kendala dan kelemahan yang ditemukan pada siklus I, diperbaiki pada siklus II, sedangkan kekuatan yang ada pada siklus I didokumentasikan pada siklus ke II berdasarkan kelemahan. Kelemahan yang ditemukan pada siklus I, disusun kembali perencanaan untuk siklus II.
Refleksi diadakan setiap satu tindakan berakhir. Dalam tahap ini peneliti dan guru mengadakan diskusi terhadap tindakan yang baru dilakukan. Hal-hal yang didiskusikan adalah : a) menganalisis tindakan yang baru dilakukan, b) mengulas dan menjelaskan perbedaan rencana dan pelaksanaan tindakan yang telah diakukan, dan 3) melakukan interverensi, pemaknaan, dan penyimpulan data yang diperoleh. Hasil refleksi ini dimanfaatkan sebagai masukan pada tindakan selanjutnya.

Data penelitian ini dikumpulkan dengan menggunakan teknik pencatatan lapangan, observasi, wawancara, dan penugasan.Untuk masing-masingnya diuraikan dibawah ini. Catatan lapangan berisi deskripsi tentang latar pengamatan dalam tindakan guru sewaktu pembelajaran menulis parafrase dalam pelajaran bahasa Indonesia. Unsur unsur yang diamati dalam pelaksanaan mengacu pada apa yang tertera pada butir-butir lembar observasi. Di samping itu juga memuat rancangan refleksi berdasarkan pengamatan yang dilakukan peneliti dengan cara observasi.

Observasi dilakukan untuk mengamati latar kelas tempat berlangsungnya pembelajaran menulis parafrase. Dengan berpedoman pada lembar-lembar observasi peneliti atau guru mengamati apa yang terjadi dalam proses pembelajaran. Unsur-unsur yang menjadi butir-butir sasaran pengamatan bila terjadi dalam proses pembelajaran ditandai dengan memberikan nilai dikolom yang ada pada lembar observasi.

Wawancara digunakan untuk memperkuat data observasi yang 
dilakukan di kelas baik unsur guru maupun siswa. Wawancara dilakukan pada guru yang melakukan tindakan intervensi langsung yang berkaitan langsung dengan perencanaan pembelajaran menulis parafrase dengan menggunakan metode mind mapping. Hasil wawancara ini digunakan sebagai bahan untuk perbaikan perencanaan yang dilakukan pada siklus berikutnya.Wawancara juga dilakukan kepada siswa untuk memperoleh data berkaitan dengan proses pembelajaran menulis parafrase. Hal ini berguna untuk memperjelaskan prilaku belajar dan proses berfikir siswa selama proses pembelajaran berlangsung.

\section{HASIL DAN PEMBAHASAN}

\section{Siklus I}

\begin{tabular}{llr}
\multicolumn{1}{c}{ Pada } & pembelajaran & Bahasa \\
Indonesia & dipaparkan & proses \\
pembelajaran & dengan menggunakan \\
metode Mind Mapping. & Dalam
\end{tabular} perencanaan pembelajaran, pelaksanaan pembelajaran Bahasa Indonesia. Penggunaan pendekatan ini terlihat dalam kegiatan awal, kegiatan inti, kegiatan akhir, refleksi tindakan. Penggunaan pendekatan dalam pembelajaran Bahasa Indonesia diwujudkan dalam bentuk rencana pelaksanaan (RPP), rencana disusun untuk dua kali pertemuan yaitu 2 × 35 menit. Rencana pembelajaran disusun dan dikembangkan berdasarkan kurikulum tingkat satuan pendidikan (KTSP) Bahasa Indonesia Kelas VI semester I dengan standar kompetensinya mengungkapkan pikiran, perasaan, dan informasi secara tertulis dalam bentuk formulir, ringkasan, dialog, dan parafrase. Pada siklus ini peneliti merencanakan akan melaksanakan pembelajaran Bahasa Indonesia dengan menggunakan metode Mind Mapping dengan Indikator yang ingin dicapai dalam pembelajaran ini adalah : 1) menyebutkan tema puisi yang dibaca, 2) mengubah puisi ke dalam bentuk prosa dengan mempertahankan makna dan isi puisi.

Pengamatan terhadap tindakan pembelajaran tema dilakukan bersamaan dengan pelaksanaan tindakan. Hal ini dilaksanakan secara intensif, objektif, dan sistimatis. Pengamatan akan dilakukan oleh teman sejawat selaku obsever pada waktu peneliti melaksanakan tindakan pembelajaran Bahasa Indonesia dengan metode Mind Mapping. Dalam kegiatan ini peneliti dan teman sejawat berusaha mengenal, dan mendokumentasikan semua indikator dari proses hasil perubahan yang telah terjadi, baik yang disebabkan oleh tindakan terencana maupun intervensi dalam pembelajaran. Keseluruhan hasil pengamatan ditulis dalam lembar observasi. Pengamatan akan dilakukan secara terus menerus mulai dari siklus 1 sampai siklus II. Pengamatan yang dilakukan pada satu siklus dapat mempengaruhi penyusunan tindakan pada siklus selanjutnya. Hasil pengamatan ini kemudian didiskusikan dengan teman sejawat dan diadakan refleksi untuk perencanaan siklus berikutnya. Obsever mengevakuasi sejauh mana tindakan yang telah dilakukan dalam memecahkan masalah. Hasil yang diperoleh dari metode Mind 


\section{Jurnal Pelangi}

Mapping pada siklus I dapat dilihat pada Gambar I.

Refleksi pada siklus I berdasarkan pengalaman dan instrumen penelitian pada kenyataannya dalam proses pembelajaran yang diperoleh bahwa tujuan pembelajaran yang kita inginkan belum tercapai. Guru sebagai fasilitator belum mampu membuat siswa aktif untuk mengajukan pertanyaan, menjawab pertanyaan dan menanggapi dalam pembelajaran ini. Sehingga cara belajar siswa belum tampak perubahan yang berarti. Pemakaian waktu yang belum efektif dan efisien belum bisa diatasi sehingga dalam pembelajaran waktu tidak mencukupi. Untuk meningkatkan hasil yang baik dan bagus maka penelitian dilanjutkan pada siklus II.

\section{Siklus II}

Pada pembelajaran
Indonesia $\begin{array}{r}\text { Bahasa } \\ \text { dipaparkan }\end{array}$
pembelajaran dengan menggunakan
metode Mind Mapping. Dalam
perencanaan pembelajaran, pelakasanaan
pembelajaran Bahasa Indonesia.
Penggunaan pendekatan ini terlihat
dalam kegiatan awal, kegiatan inti,
kegiatan akhir, refleksi tindakan. Secara
rinci dapat dilihat pada paparan berikut
ini.

Penggunaan pendekatan dalam pembelajaran Bahasa Indonesia diwujudkan dalam bentuk rencana pelaksanaan (RPP), rencana disusun untuk satu kali pertemuan yaitu 2 x 35 menit. Rencana pembelajaran disusun dan dikembangkan berdasarkan kurikulum tingkat satuan pendidikan (KTSP) Bahasa Indonesia Kelas VI semester I dengan standar kompetensinya Mengubah puisi ke dalam bentuk prosa dengan tetap memperhatikan makna puisi. Berdasarkan analisis bahan ajar, ditetapkan materi pokoknya diambil dari buku Bahasa Indonesia kelas VI penerbit BSE dan buku penunjang yang lain yang relevan. Hasil Metode Mind Mapping pada siklus II dapat lihat pada gambar 2 .

Refleksi pada siklus II berdasarkan pengalaman dan intrumen penelitian yang di peroleh peneliti sebagai guru kelas dengan teman sejawat adalah pada kenyataannya pada proses pembelajaran tematik yang diinginkan ini sudah tercapai. Guru sebagai fasilitator mampu membuat siswa aktif dalam mengajukan pertanyaan, menjawab pertanyaan dan menanggapinya. Sehingga dengan pembelajaran ini siswa lebih bergairah dan bersemangat dalam belajar. Setelah dilaksanakan pembelajaran tematik pada siklus I sampai siklus II maka terlihat hasil perbandingan seperti Gambar 2. 


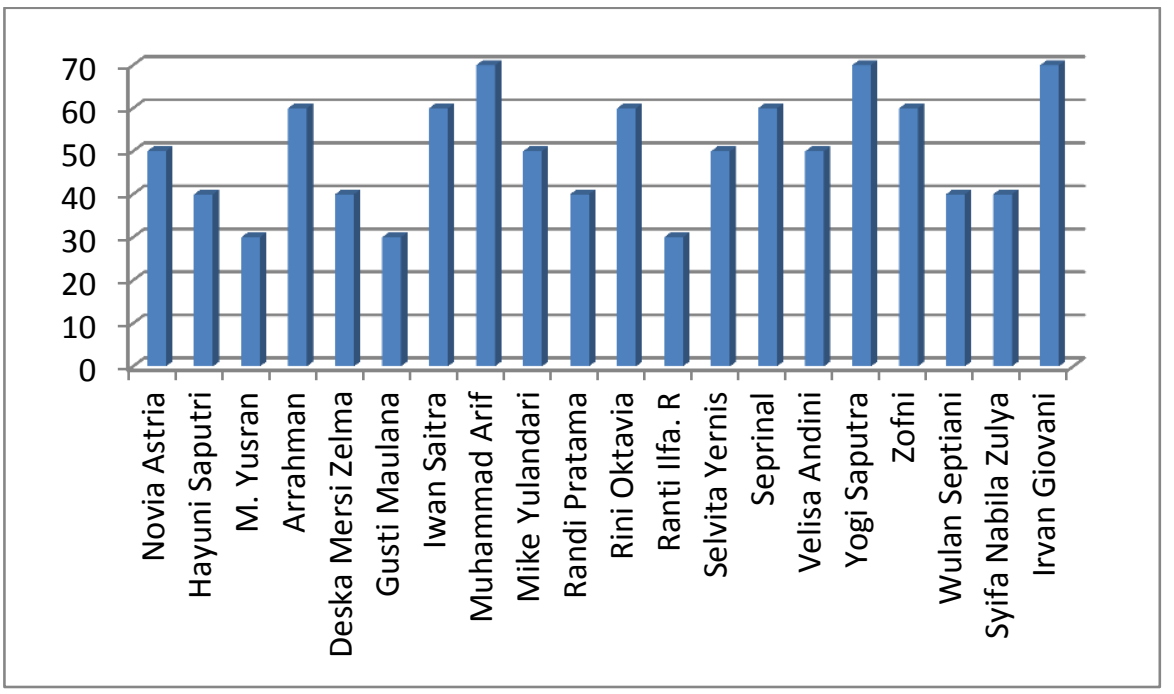

Gambar 2. Hasil Belajar Siswa Siklus I

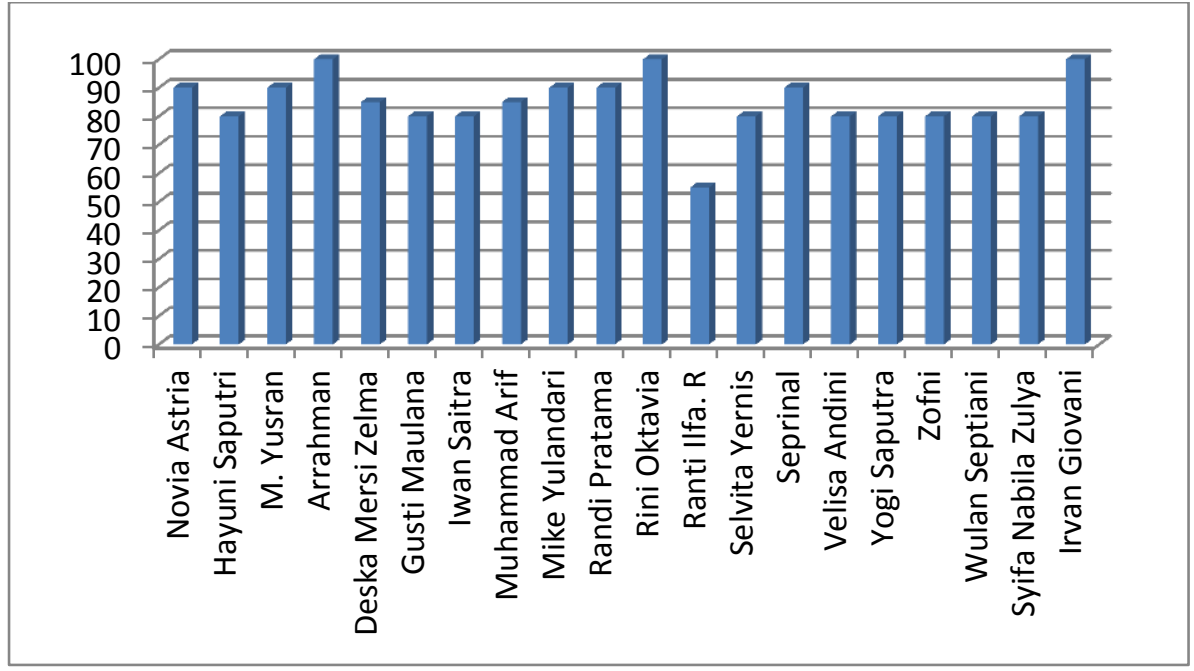

Gambar 3. Grafik Hasil Belajar Siswa Siklus II

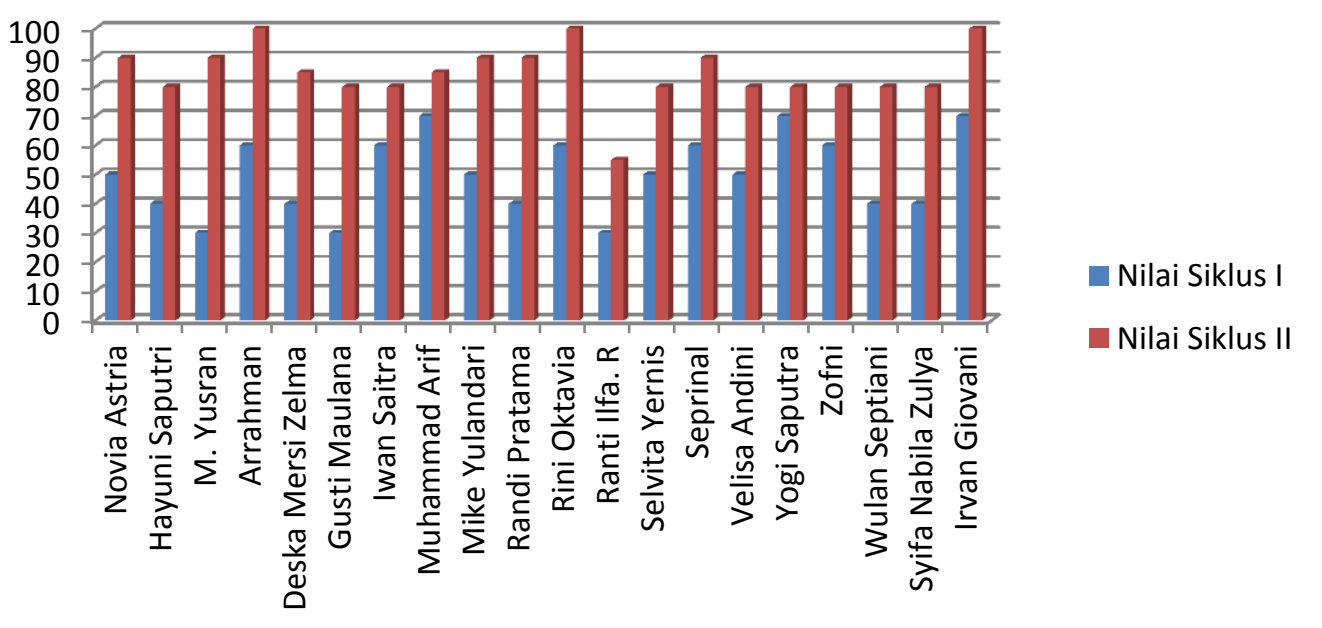

Gambar 4 Hasil Belajar Siswa Pada Siklus I dan Siklus II 
Pada siklus I dilakukan pengamatan oleh teman sejawat pada guru dan siswa yang sedang melaksanakan proses pembelajaran. Guru sudah melaksanakan pembelajaran Bahasa Indonesia namun siswa belum aktif mengikutinya. Pada saat pembelajaran berlangsung pun siswa kurang aktif untuk bertanya, mengajukan pertanyaan serta menanggapinya. Pada akhir pembelajaran guru menjelaskan pelajaran yang menyangkut tema yang dipelajari, serta memberi contoh cara menjawab, mengajukan pertanyaan serta menanggapinya. Siswa mendengarkan penjelasan guru dengan senang dan penuh semangat. Selanjutnya guru memberikan tugas rumah dan menyampaikan pembelajaran untuk siklus II.

Pada siklus II ini proses pembelajaran Bahasa Indonesia masih dilakukan pengamatan oleh teman sejawat pada peneliti sebagai guru kelas dengan siswa dalam melaksanakan pembelajaran. Pembelajaran berlangsung dengan baik, siswa pun lebih aktif dan bersemangat pada saat masing-masing siswa disuruh membaca teks bacaan ke depan kelas. Pada saat masing-masing siswa disuruh ke depan kelas siswa lebih aktif dan lebih bersemangat lagi dan dalam membaca hasil diskusi kelompok. Dalam proses pembelajaran berlangsung sudah banyak siswa yang bertanya, yang mengajukan pertanyaan dan bahkan ada yang menanggapinya. Pada siklus II ini banyak sekali perubahan dan penigkatan yang signitif dari proses pengajaran guru dan proses pembelajaran dari siswa sehingga dapat dilihat nilai persentasi dari ketuntasan anak yang mencapai
84.75. sedangkan pada siklus I persentasi ketuntasan anak hanya mencapai 50.

\section{PENUTUP}

Berdasarkan hasil penelitian dan pembahasan serta kesimpulan yang diperoleh, dapat dikemukakan sasaran sebagai berikut:

1. Agar rencana pelaksanaan pembelajaran bagus maka guru perlu lebih kreatif dalam merancang pembelajaran yang sesuai dengan situasi dunia nyata, memperhatikan sumber materi ajar, dan sesuai dengan karakteristik siswa dan lingkungan dimana siswa tinggal.

2. Dalam pelaksanaan pembelajaran disarankan agar dalam memberikan materi disesuaikan dengan konteks sehari-hari siswa, perlu memberikan perhatian, bimbingan dan motivasi belajar secara sungguh-sungguh kepada siswa yang berkemampuan kurang pasif dalam kelompok, karena siswa yang demikian sering menggantungkan diri pada temannya.

3. Agar hasil belajar yang diharapkan dapat meningkat, sebaiknya guru tidak hanya melakukan penilaian hasil saja, tetapi juga melakukan penilaian proses untuk melihat keaktifan dan kemampuan siswa dalam menemukan jawaban dari suatu permasalahan yang sudah dirumuskan.

\section{UCAPAN TERIMA KASIH}

Penelitian ini terlaksana karena adanya kerjasama pihak SD Negeri 16 Kampung Parit Kecamatan Ampek 
Nagari dengan UPT Dinas Pendidikan yang telah membantu untuk kelancaran penyelesaikan penelitian ini.

\section{DAFTAR PUSTAKA}

Akhmad, Sudrajat. 2008. Pengertian Pendekatan, Strategi, Metode, Teknik, taktik, dan Model Pembelajaran.http://akhmadsudraj at.wordpress.com/2008/09/12/peng ertianpendekatan strategi-metodeteknik-taktik-dan model pembelajaran. Diakses tanggal 23 Desember 2010

Anne. 2010. Proses Menulis. http://www.anneahira.com/-prosesmenulis-.htm. Diakses Tanggal 2 Januari 2011

Badan Standar Nasional Pendidikan. 2006. Panduan Penyusunan Kurikulum Tingkat Satuan pendidikan Jenjang Pendidikan Dasar dan Menengah. Jakarta: BSNP

Evanz. 2010. Makalah Parafrase. http://blacxadleevanz.blogspot.co m/2010/01/makalahparafrase.html. Diakses tanggal 2 Januari 2011.

Farida Rahim, dkk. 2009. Mata Pelajaran Guru Kelas SD. Padang: UNP.

Fauzan. 2009. Definisi dan Tujuan Menulis.

http://fauzanprince.blog.com/2009/ 02/13/definisi-dan-tujuanmenulis/. Diakses Tanggal 24 Februari 2011.
Hamzah B. Uno. 2009. Model Pembelajaran. Jakarta: Bumi Aksara

Henry Guntur Tarigan. 1997. Menulis Sebagai suatu Keterampilan Berbahasa.Bandung: Angkasa.

Isah Cahyani dan Iyos. 2007. Pendidikan Bahasa Indonesia. Bandung: UPI PRESS

Mursal Esten. 1992. Memahami Puisi. Jakarta: Angkasa Bandung

Muchlisoh, dkk. 1994. Pendidikan Bahasa Indonesia 3. Universitas Terbuka: Jakarta

Nawaafila. 2010. Mind Mapping. http://nawaafila.wordpress.com/20 10/04/01/mind-mapping/. Diakses tanggal 29 Desember 2010

Novi Resmini dan Dadan Juanda. 2008. Pendidikan Bahasa dan Sastra di Kelas Tinggi. Bandung: UPI PRESS.

Poerwadarminta. 1976. Kamus Umum Bahasa Indonesia. Jakarta: Balai Pustaka.

Rina. 2010. keterampilan menulis. http://rina.wordpress.com/2010/04/ 02/keterampilan-menulis. Diakses tanggal 5 Januari 2010.

Ritawati Mahyududdin dan Yetty Ariani. 2007. Hand Out Metodologi Penelitian tindakan Kelas. Padang: UNP.

Rochiati Wiriaatmadja.2005. Metode Penelitian Tindakan Kelas. Bandung: Rosda Karya. 


\section{Jurnal Pelangi}

Saleh Abas. 2006. Pembelajaran Bahasa Indonesia yang Efektif di Sekolah Dasar. Jakarta: Depdiknas

Slamet Tri Hartanto. 2007. Pendalaman Materi untuk Guru Pemandu MGMP SMA Bahasa Indonesia. LPMP Jawa Tengah.

Tony Buzan. 2007. Buku Pintar Mind Mapp untuk Anak. Jakarta : PT. Gramedia Pustaka Utama

Toni Buzan. 2004. Mind Map untuk Meningkatkan Kreativitas. Jakarta: Gramedia Pustaka Utama.

Wina Sanjaya. 2009. Strategi Pembelajaran Berorientasi
Standar Proses Pendidikan. Jakarta: Kencana

Wywid. 2009. Model Pembelajaran Parafrase.

http://wywid.wordpress.com/2009/ 11/30/model-pembelajaranparafrase/. Diakses tanggal 2 Januari 2011

Wycoff, Joyce. 2003. Menjadi Super Kreatif melalui Metode Pemetaan Pikiran. Bandung: Kaifa.

Yovan P. Putra. 2008. Memori dan Pembelajaran Efektif. Bandung: CV. Yrama Widya 